\title{
Seeds extract of three Artocarpus species: Their in-vitro antibacterial activities against multidrug-resistant (MDR) Escherichia coli isolates from urinary tract infections (UTIs)
}

\author{
MUHAMMAD EVY PRASTIYANTO \\ Department of Medical Labolatory Technology, Faculty of Nursing and Health Sciences, Universitas Muhammadiyah Semarang. JL. Kedungmundu \\ Raya No.18, Tembalang, Semarang, Semarang 50273, Indonesia. Tel: +62-24- 74760296, email: evy_prastiyanto@unimus.ac.id
}

Manuscript received: 6 September 2021. Revision accepted: 23 September 2021.

\begin{abstract}
Prastiyanto ME. 2021. Seeds extract of three Artocarpus species: Their in-vitro antibacterial activities against multidrugresistant (MDR) Escherichia coli isolates from urinary tract infections (UTIS). Biodiversitas 22: 4362-4368. Multidrug-resistant (MDR)$E$. coli is a major cause and has become a very serious problem in urinary tract infections (UTIs). As a result, it requires an antibacterial agent derived from biological materials. It has been reported that the seeds of three species of Artocarpus (A. heterophyllous, A. champeden, and A. camansi) have antibacterial properties against Methicillin-Resistant Staphylococcus aureus (MRSA). However, there are three other Artocarpus species in Indonesia, i.e., keledang (A. lanceipolius), tarra (A. elasticus), and terap (A. Odoratissimus) whose antibacterial property has not been investigated. To minimize the research gap, this study aims to determine the antibacterial activity of seed extracts of A. lanceipolius, A. elasticus, and A. odoratissimus against MDR-E. coli isolates of UTIs. Antibacterial activity was evaluated using the agar well diffusion assay. The microdilution method was used to determine the minimum inhibitory concentration (MIC) and minimum bactericidal concentration (MBC) values. The results revealed that the seed extracts of A. lanceipolius, A. elasticus, and A. odoratissimus have the potential as antibacterial agents against MDR-E. coli isolate of UTIs. A. elasticus seed extract shows the widest zone of inhibition in the range of 7.0-13.3 mm and the smallest MIC and MBC values of $6.25-12.5 \mathrm{mg} / \mathrm{mL} \mathrm{and} 12.5-25 \mathrm{mg} / \mathrm{mL}$, respectively. In conclusion, A. lanceipolius, A. elasticus, and A. odoratissimus seed extracts have the potential to be developed as antibacterial agents against UTI-causing MDR-E. coli. Further in vivo research and determining the mode of action of antibacterial activity are needed.
\end{abstract}

Keywords: Antibacterial activity, Artocarpus, MDR-E. coli, seeds, UTI

\section{INTRODUCTION}

Urinary tract infections (UTIs) are microbe-caused infections that are a major cause of morbidity in humans, particularly in children and newborns. Approximately $8 \%$ of girls and $2 \%$ of boys experience at least one UTI between the ages of 1 month and 11 years (Simões e Silva et al. 2020). UTIs can affect the bladder, urethra, and kidneys, and it is estimated that approximately 150 million people worldwide suffer from UTIs each year (Zubair et al. 2019). In 2013, it cost approximately $\$ 630$ million for UTI medication and treatment in the United States (Millner and Becknell 2019).

The most common pathogens that cause UTIs are Gram-negative bacteria such as Escherichia coli, Klebsiella oxytoca, Enterobacter, Proteus mirabilis, Proteus vulgaris, Citrobacter spp., Acinetobacter baumannii, and Pseudomonas aeruginosa (Mishra et al. 2013), Grampositive such as Enterococcus sp., Staphylococcus saprophyticus, and Staphylococcus aureus (Millner and Becknell 2019). Meanwhile, the fungi that cause UTIs include Candida sp. (such as Candida albicans, Candida glabrata, Candida utilis, Candida kefyr, Candida guilliermondii, and Candida tropicalis) and Rhodotorula sp. (Behzadi et al. 2010). E. coli is the most common pathogen responsible for UTIs, accounting for approximately $80 \%$ to $90 \%$ of UTI cases (Edlin et al. 2013).

Commonly used antimicrobial agents for UTIs are $\beta$ lactams, aminoglycosides, quinolones, and trimethoprimsulfamethoxazole (Adwan et al. 2014). However, excessive and uncontrolled use of antimicrobial agents causes bacterial strains to become multidrug-resistant (MDR). $E$. coli strains that are resistant to extended-spectrum cephalosporins producing extended-spectrum $\beta$-lactamases (ESBLs) (Mukherjee et al. 2013) emerged recently and are spreading worldwide rapidly. This proves that the MDR-E. coli is now a serious public health issue that must be addressed and therefore, antibacterial agents from natural products are required to overcome bacterial resistance.

Antibacterial agents derived from biological sources include mushrooms (Prastiyanto et al. 2016; 2020b), lactic acid bacteria (Lestari et al. 2019), latex (Prastiyanto et al. 2020c), fruits (Prastiyanto et al. 2020d), and seeds (Prastiyanto et al. 2020a). Many studies on antimicrobial agents report the importance of plants as alternative antimicrobial agents (Prastiyanto et al. 2021a; Prastiyanto et al. 2021b). It has been reported that seeds of three species of Artocarpus, namely jackfruit (A. heterophyllus), cempedak (A. champeden), and breadfruit (A. camansi) have the potential as antibacterial agents against Methicillin-Resistant Staphylococcus aureus (MRSA) 
(Prastiyanto et al. 2020a). Aside from the three species of Artocarpus, other species of Artocarpus are found throughout Indonesia, namely A. lanceipolius, A. elasticus, and $A$. odoratissimus but no study has reported the antibacterial properties of the seeds of these species. This study aims to fill the research gap by determining the antibacterial potential of $A$. lanceipolius, A. elasticus, and A. odoratissimus seeds against MDR-E. Coli causing UTIs.

\section{MATERIALS AND METHODS}

\section{Seed collection and extractions}

The seeds of keledang (A. lanceipolius), tarra (A. elasticus), and terap (A. odoratissimus) (Figure 1.) were collected in February 2021 from different regions in Indonesia. A. lanceipolius was collected from East Kutai District, East Kalimantan ( $\left.1^{\circ} 05^{\prime} 31.9^{\prime \prime} \mathrm{N} 116^{\circ} 55^{\prime} 00.9^{\prime \prime} \mathrm{E}\right)$, A. elasticus was obtained from Luwu District, South Sulawesi ( $\left.3^{\circ} 18^{\prime} 19.4^{\prime \prime S} 120^{\circ} 18^{\prime} 26.4^{\prime \prime E}\right)$, while A. odoratissimus was gathered from Tabalong District, South Kalimantan $\left(2.198547^{\circ} \mathrm{S} 115.349065^{\circ} \mathrm{E}\right)$. The local names of the plants have been confirmed by the owners and the scientific names of the plants were identified in the Department of Biology, Universitas Negeri Semarang
The collected seeds were washed under running water to remove dirt. The seeds were dried under the sun for seven days, then ground to obtain seed powder. Extraction was performed by maceration with a $96 \%$ ethanol solvent. One hundred grams of each seed powder was extracted with $300 \mathrm{~mL}$ of ethanol for 24 hours at room temperature. The solvent replacement was carried out every 24 hours until the solution became clear, assuming that all active compounds in the powder had dissolved in ethanol. The supernatant was filtered with Whatman No.1 paper. Filtrates were concentrated using a rotary evaporator at a temperature of $40^{\circ} \mathrm{C}$ to obtain crude extract.

\section{Isolation of $E$. coli from urine and the antibiotic sensitivity tests}

MDR-E. coli was isolated from urine samples collected from patients suffering from UTIs in RS. Dr. Kariadi Semarang, Central Java, Indonesia. All isolates were identified using MacConkey Agar (MCA) media, as well as biochemical tests with Vitek®MS and bacterial sensitivity tests using the Clinical Laboratory Standard Institute M100-S25 for minimum inhibitory concentration (MIC) interpretation (CLSI 2019).

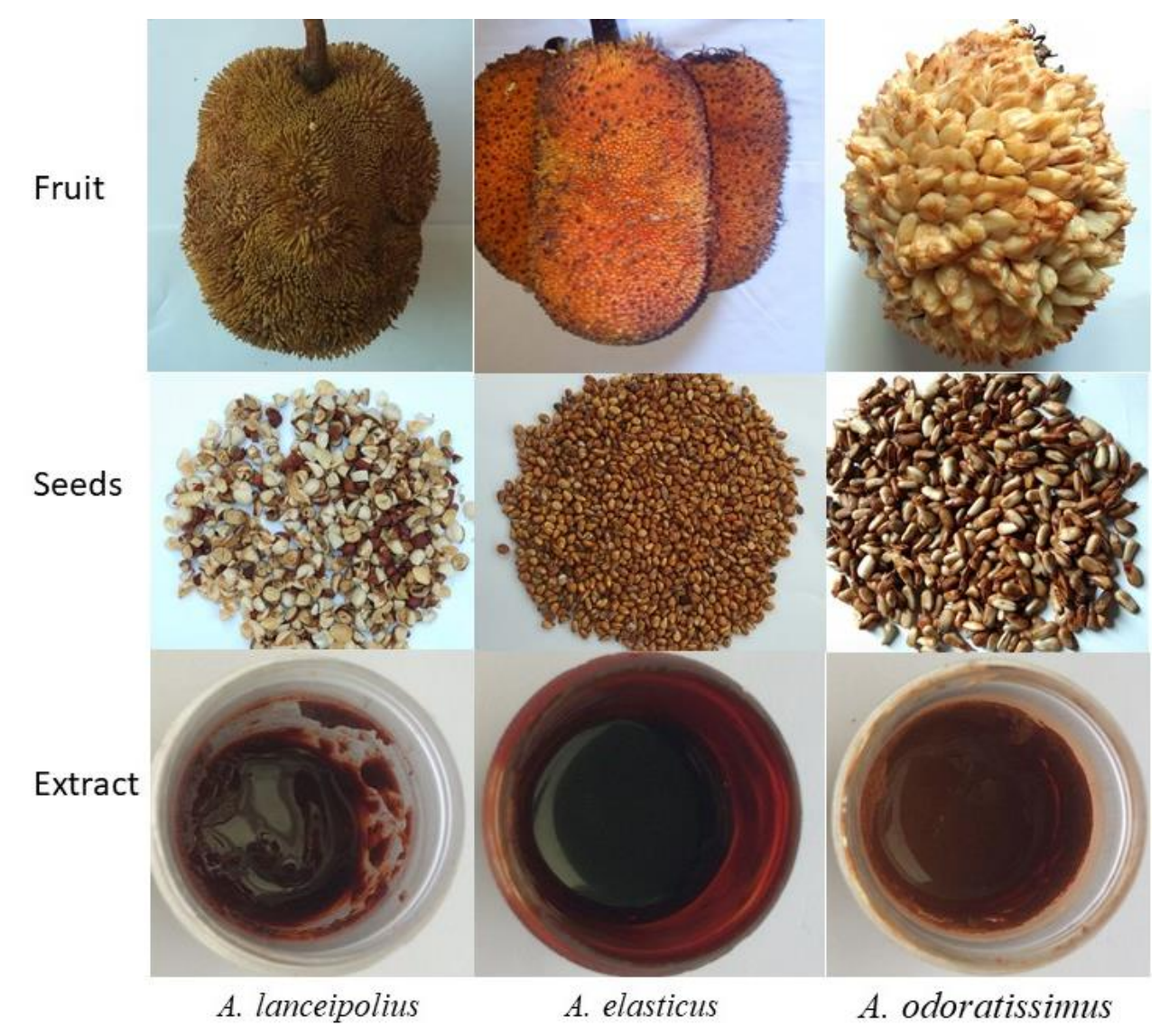

Figure 1. Fruits, seeds, and extracts of three species of Artocarpus 
Antibacterial activity of seed extracts against MDR-E. coli Agar well diffusion

The antibacterial activity of the seed extract of three Artocarpus species was evaluated using a well-diffusion assay (Prastiyanto et al. 2020c). All isolates of MDR-E. coli obtained from UTI patients were cultured on blood agar plate media and incubated for 24 hours at $35 \pm 3^{\circ} \mathrm{C}$. All MDR-E. coli isolates were standardized with 0.5 McFarland. Each isolate was inoculated on Muller Hilton Agar (MHA) media using a sterile cotton swab. After five minutes, the MHA media was perforated with a cork borer $(0.5 \mathrm{~cm}$ in diameter). Four holes for each extract concentration: $0.1 \mathrm{mg} / \mathrm{mL}, 1 \mathrm{mg} / \mathrm{mL}, 10 \mathrm{mg} / \mathrm{mL}$, and 100 $\mathrm{mg} / \mathrm{mL}$ ). The extract was dissolved with dimethyl sulfoxide (DMSO). Each test was carried out in four replicates. One hundred $\mu \mathrm{L}$ of each concentration of the extract was added to each well and then incubated for $16-20$ hours at $35 \pm 2{ }^{\circ} \mathrm{C}$. Positive controls included ampicillin, ceftriaxone, aztreonam, ciprofloxacin, gentamicin, and meropenem (MRP), while DMSO was used as a negative control. Antibacterial activity of seed extract against MDR-E. coli was determined by measuring the diameter of the inhibition zone $(\mathrm{mm})$. The widest zone of inhibition is the best antibacterial activity.

\section{Determination of minimum inhibitory concentration (MIC)}

The MIC value of each extract was determined by the microdilution method using Muller Hilton broth (MHB) media (CLSI 2018) on a microwell plate (Prastiyanto et al. 2020c). In this test, a slight modification was carried out by adding 2,3,5-Triphenyltetrazolium chloride $0.05 \%$ to the MHB medium (Tsukatani et al. 2009). $100 \mu \mathrm{L}$ of MHB was added to each well, and $100 \mu \mathrm{L}$ of seed extract was added to the first well, followed by a series of dilutions until reaching well 12th. After finish diluting, $10 \mu \mathrm{L}$ of MDR-E. coli bacterial suspension $0.5 \mathrm{McF}$ arland standards $\left(1.5 \times 10^{8} \mathrm{CFU} / \mathrm{mL}\right)$ was added to each well except negative control. The microwell plate was incubated fr 18 hours at $37^{\circ} \mathrm{C}$. After incubation, the MIC value was determined by observing the lowest concentration of seed extract that inhibited the growth of MDR-E. coli bacteria. It was indicated by the color change on the microwell plate and compared to the control. The best antibacterial activity of the extract was indicated by the lowest MIC value.

\section{Determination of minimum bactericidal concentration $(M B C)$}

MBC was the continuation of MIC. The mixture of MIC well was sub-cultured on a 5\% sheep BAP at $35 \pm$ $2)^{\circ} \mathrm{C}$ and incubated for 16-20 hours. The MBC value was determined by observing the growth of bacteria on BAP media. The value of $\mathrm{MBC}$ is defined as the lowest concentration of seed extract which shows that MDR-E. coli bacteria cannot grow (Yin et al. 2018). The best antibacterial activity was specified by the lowest MBC value.

\section{Phytochemical screening of extract}

Phytochemical analysis (tannins and flavonoids) of the crude extracts of A. lanceipolius, A. elasticus, and A. odoratissimus seeds was carried out using previously described methods (Eve et al. 2020)

\section{RESULTS AND DISCUSSION}

\section{Extract yield}

The results of seed extract of three species of Artocarpus (A. lanceipolius, A. elasticus, and A. odoratissimus) with ethanol as a solvent are presented in Table 1. A. elasticus showed a higher yield than the other two species. This shows that A. elasticus seeds have higher chemical substances that can be extracted in ethanol. Ethanol solvents produced extracts with better antibacterial potential than the other solvents (Prastiyanto et al. 2020d). These results are in line with the results of previous research on an ethanol extract of A. heterophyllus seeds which produced higher solubility of the active substances than the hexanes (Eve et al. 2020). This can be attributed to the higher solubility of the seed phytochemical compounds of the seeds in ethanol than in hexane. The high polarity of ethanol causes strong interactions with most of the polar phytochemical compounds from the seed extract, so it has a better extraction potential when compared to hexane which extracts nonpolar phytochemical compounds (Sbihi et al. 2018).

\section{MDR-E. coli isolates from urinary tract infections (UTIs)}

MDR-E. coli was isolated from urine samples of patients with UTIs. The results of the bacterial sensitivity test to antibiotics are presented in Table 2. The results of the identification and sensitivity test of bacteria to antibiotics show that $E$. coli from UTI patients was an MDR strain because it was resistant to at least three classes of antibiotics. MDR-E. coli strain \#1 was resistant to $\beta$ lactams (penicillin and cephalosporin), monobactams (aztreonam), aminoglicosides (gentamicin), and fluoroquinolones (ciprofloxacine). MDR-E. coli strain \#2 was resistant to $\beta$-lactam antibiotics, aminoglicosides and fluroquinolone. MDR-E. coli strain \#3 was resistant to $\beta$ lactam antibiotics, monobactams, and fluoroquinolones. MDR- $E$. coli strain \#4 was resistant to $\beta$-lactam antibiotics, monobactams, and aminoglicosides. Meanwhile, the MDRE. coli strain \#5 was resistant to $\beta$ lactams, monobactams, carbapenem, and fluoroquinolones groups. E. coli bacterium is the major cause of UTIs in the world. The results of this study revealed that five isolates of $E$. coli collected from urine samples of UTI patients were $E$. coli producing extended-spectrum beta-lactamase (ESBL)because all of these isolates were resistant to penicillin, cephalosporin, and monobactam antibiotics. Isolate \#5 was an ESBL-producing E. coli and an isolate that was resistant to the carbapenem group. According to Mazzariol et al. (2017), ESBL-producing E. coli is the main cause of MDR E. coli cases that trigger UTIs (Mazzariol et al. 2017). 
The antibacterial activities of extracts against MDR- $E$. coli Agar well diffusion assay

The antibacterial activities of $A$. lanceipolius, $A$. elasticus, and $A$. odoratissimus seed extracts were evaluated using agar well diffusion assay against MDR- $E$. coli bacteria from UTI patients. The antibacterial activities of the seed extracts at concentrations of $0.1 \mathrm{mg} / \mathrm{mL}, 1$ $\mathrm{mg} / \mathrm{mL}, 10 \mathrm{mg} / \mathrm{mL}$, and $100 \mathrm{mg} / \mathrm{mL}$ were determined by measuring the inhibition zone diameter $(\mathrm{mm})$ against five isolates of MDR-E. coli (Table 3)

The results of this study show that three extracts of Artocarpus seeds had antibacterial activities against MDR$E$. coli, as indicated by the presence of an inhibition zone. The inhibition zone of $A$. lanceipolius seed extract against MDR-E. coli was from $0.0 \pm 0.0$ to $11.8 \pm 0.8 \mathrm{~mm}$, while its inhibition zone against $E$. coli ATCC 25922 was wider, i.e., from $7.3 \pm 0.4 \mathrm{~mm}$ to $13.5 \pm 0.5 \mathrm{~mm}$. The inhibition zone of $A$. elasticus seed extract against MDR E. coli was from $7.0 \pm 0.0 \mathrm{~mm}$ to $13.3 \pm 0.4 \mathrm{~mm}$, while its inhibition zone against standard E. coli ATCC 25922 was wider, i.e.,
$10.3 \pm 1.1 \mathrm{~mm}$ to $14.8 \pm 0.4 \mathrm{~mm}$. The inhibition zone of $A$. odoratissimus seed extract against MDR E. coli was $6.0 \pm$ $0.0 \mathrm{~mm}-12.5 \pm 0.5 \mathrm{~mm}$, while the inhibition zone against E. coli ATCC 25922 was $9.0 \pm 0.7 \mathrm{~mm}-14.0 \pm 0.7 \mathrm{~mm}$. The findings showed that the seed extracts of three Artocarpus species' had a wider inhibition zone than the control antibiotics. In addition, the inhibition zone against the $E$, coli standard was wider than that of the MDR- $E$. coli. A. elasticus seed extract had better antibacterial activities than $A$. lanceipolius and $A$. odoratissimus extracts because it had a wider inhibition zone than the other two extracts.

Table 1. The extract yield of three species of Artocarpus

\begin{tabular}{llcl}
\hline Scientific name & Local name & Part of plants & Yield (\%) \\
\hline A. lanceipolius & Keledang & Seeds & 8.80 \\
A. elasticus & Tarra & Seeds & 21.00 \\
A. odoratissimus & Terap & Seeds & 16.80 \\
\hline
\end{tabular}

Table 2. Resistance screening of E,coli isolated from urine samples of UT I patients to several antibiotics

\begin{tabular}{|c|c|c|}
\hline Species & Source & Antibiotic resistance pattern \\
\hline MDR-E. coli \#1 & 34 years, female, urine & $\begin{array}{l}\text { Ampicillin, sulbactam, tazobactam, cefazolin, ceftazidime, ceftriaxone, cefepime, } \\
\text { aztreonam, gentamicin, ciprofloxacine }\end{array}$ \\
\hline MDR-E. coli \#2 & 29 years, male, urine & $\begin{array}{l}\text { Ampicillin, sulbactam, tazobactam, cefazolin, ceftazidime, ceftriaxone, cefepime, } \\
\text { gentamicin, ciprofloxacine, sulfamethoxazole }\end{array}$ \\
\hline MDR-E. coli \#3 & 9 months, male, urine & $\begin{array}{l}\text { Ampicillin, cefazolin, ceftazidime, ceftriaxone, cefepime, aztreonam, ciprofloxacin } \\
\text { nitrofurantoin, sulfamethoxazole }\end{array}$ \\
\hline MDR-E. coli \#4 & 2 years, male, urine & $\begin{array}{l}\text { Ampicillin, cefazolin, ceftazidime, ceftriaxone, cefepime, aztreonam, gentamicin, } \\
\text { sulfamethoxazole }\end{array}$ \\
\hline MDR-E. coli \#5 & 2 years, male, urine & $\begin{array}{l}\text { Ampicillin, sulbactam, tazobactam, cefazolin, ceftazidime, ceftriaxone, cefepime, } \\
\text { aztreonam, ertapenem, meropenem, ciprofloxacine, sulfamethoxazole }\end{array}$ \\
\hline
\end{tabular}

Table 3. Diameter of inhibition zones of seed extract of three species of Artocarpus and several antibiotics standard as the positive control against MDR-E. coli and E. coli ATCC 25922

\begin{tabular}{|c|c|c|c|c|c|c|c|}
\hline \multirow{3}{*}{ Seed extract } & \multirow{3}{*}{$\begin{array}{c}\text { Concentration } \\
(\mathrm{mg} / \mathrm{mL})\end{array}$} & \multicolumn{6}{|c|}{ The inhibition zones (mm) against } \\
\hline & & \multicolumn{5}{|c|}{ MDR-E. coli } & \multirow{2}{*}{$\begin{array}{c}\text { E. coli standard } \\
\text { ATCC } 25922\end{array}$} \\
\hline & & 1 & 2 & 3 & 4 & 5 & \\
\hline \multirow[t]{4}{*}{ A. lanceipolius } & 0.1 & $6.3 \pm 0.4$ & $7.3 \pm 0.4$ & $7.3 \pm 0.4$ & $0.0 \pm 0.0$ & $0.0 \pm 0.0$ & $7.3 \pm 0.4$ \\
\hline & 1 & $7.0 \pm 0.7$ & $8.3 \pm 0.4$ & $7.3 \pm 0.4$ & $9.0 \pm 0.8$ & $7.5 \pm 0.5$ & $8.8 \pm 0.8$ \\
\hline & 10 & $9.0 \pm 0.4$ & $10.5 \pm 0.5$ & $10.3 \pm 0.8$ & $10.0 \pm 0.7$ & $9.3 \pm 0.4$ & $10.3 \pm 0.4$ \\
\hline & 100 & $10.0 \pm 0.5$ & $11.8 \pm 0.8$ & $10.5 \pm 0.9$ & $10.5 \pm 0.5$ & $10.8 \pm 0.4$ & $13.5 \pm 0.5$ \\
\hline \multirow[t]{4}{*}{ A. elasticus } & 0.1 & $9.0 \pm 0.7$ & $7.0 \pm 0.0$ & $11.3 \pm 0.8$ & $9.5 \pm 0.5$ & $7.0 \pm 0.0$ & $10.3 \pm 1.1$ \\
\hline & 1 & $9.8 \pm 0.4$ & $10.0 \pm 0.7$ & $11.8 \pm 0.4$ & $10.0 \pm 0$ & $10.5 \pm 0.5$ & $14.8 \pm 0.4$ \\
\hline & 10 & $10.8 \pm 0.4$ & $9.3 \pm 0.4$ & $12.3 \pm 0.4$ & $11.0 \pm 0$ & $12.3 \pm 0.4$ & $10.3 \pm 0.4$ \\
\hline & 100 & $11.8 \pm 0.4$ & $12.0 \pm 0.0$ & $12.8 \pm 0.4$ & $11.5 \pm 0.5$ & $13.3 \pm 0.4$ & $14.3 \pm 0.4$ \\
\hline \multirow{4}{*}{ A. odoratissimus } & 0.1 & $7.3 \pm 0.4$ & $7.0 \pm 0.0$ & $7.3 \pm 0.4$ & $6.0 \pm 0.0$ & $6.0 \pm 0.0$ & $9.0 \pm 0.7$ \\
\hline & 1 & $7.8 \pm 0.4$ & $7.5 \pm 0.5$ & $8.5 \pm 0.5$ & $8.0 \pm 1.0$ & $7.3 \pm 0.4$ & $10.5 \pm 0.5$ \\
\hline & 10 & $9.5 \pm 0.5$ & $9.3 \pm 0.4$ & $11.5 \pm 0.5$ & $10.5 \pm 0.5$ & $11.8 \pm 0.4$ & $10.3 \pm 0.5$ \\
\hline & 100 & $11.3 \pm 0.4$ & $11.5 \pm 0.5$ & $12.5 \pm 0.5$ & $10.8 \pm 0.8$ & $12.5 \pm 0.5$ & $14.0 \pm 0.7$ \\
\hline \multirow[t]{6}{*}{ Antibiotic } & AMP $10 \mu \mathrm{g}$ & $0.0 \pm 0.0$ & $0.0 \pm 0.0$ & $0.0 \pm 0.0$ & $0.0 \pm 0.0$ & $0.0 \pm 0.0$ & $0.0 \pm 0.0$ \\
\hline & CTR $30 \mu \mathrm{g}$ & $0.0 \pm 0.0$ & $0.0 \pm 0.0$ & $0.0 \pm 0.0$ & $0.0 \pm 0.0$ & $0.0 \pm 0.0$ & $16.0 \pm 0.0$ \\
\hline & ATM $30 \mu \mathrm{g}$ & $0.0 \pm 0.0$ & $0.0 \pm 0.0$ & $0.0 \pm 0.0$ & $0.0 \pm 0.0$ & $0.0 \pm 0.0$ & $23.0 \pm 0.0$ \\
\hline & CIP $5 \mu \mathrm{g}$ & $0.0 \pm 0.0$ & $0.0 \pm 0.0$ & $0.0 \pm 0.0$ & $2.0 \pm 0.0$ & $0.0 \pm 0.0$ & $35.0 \pm 0.0$ \\
\hline & GEN $10 \mu \mathrm{g}$ & $9.0 \pm 0.0$ & $7.0 \pm 0.0$ & $10.0 \pm 0.0$ & $7.0 \pm 0.0$ & $1.0 \pm 0.0$ & $19.0 \pm 0.0$ \\
\hline & MRP $10 \mu \mathrm{g}$ & $9.0 \pm 0.0$ & $10.0 \pm 0.0$ & $9.0 \pm 0.0$ & $11.0 \pm 0.0$ & $0.0 \pm 0.0$ & $33.0 \pm 0.0$ \\
\hline DMSO & - & $0.0 \pm 0.0$ & $0.0 \pm 0.0$ & $0.0 \pm 0.0$ & $0.0 \pm 0.0$ & $0.0 \pm 0.0$ & $0.0 \pm 0.0$ \\
\hline
\end{tabular}




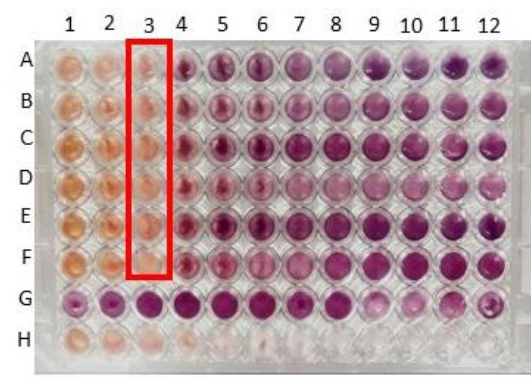

A. lanceipolius

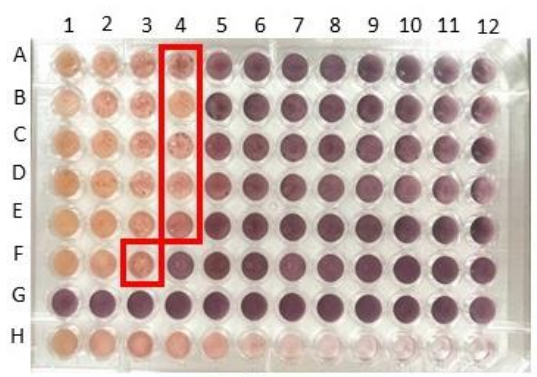

A. elasticus

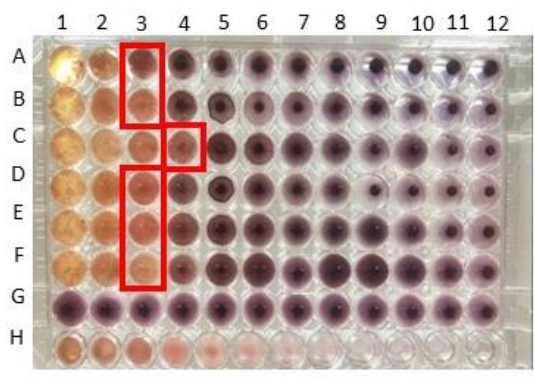

A. odoratissimus

Figure 2. MIC values of A. lanceipolius, A. elasticus and A. odoratissimus seed extracts against MDR-E. coli: A. MDR-E. coli \#1, B. MDR-E. coli \#2, C. MDR-E. coli \#3, D. MDR-E. coli \#4, E. MDR-E. coli \#5, F. E. coli ATCC 25922. At concentration of: 1). 50 $\mathrm{mg} / \mathrm{mL}, 2) .25 \mathrm{mg} / \mathrm{mL}, 3) .12 .5 \mathrm{mg} / \mathrm{mL}$, 4). $6.25 \mathrm{mg} / \mathrm{mL}, 5) .3 .13 \mathrm{mg} / \mathrm{mL}, 6$ ). $1.56 \mathrm{mg} / \mathrm{mL}, 7) .0 .78 \mathrm{mg} / \mathrm{mL}, 8) .039 \mathrm{mg} / \mathrm{mL}, 9) 0.19$ $\mathrm{mg} / \mathrm{mL}$, 10) $0.09 \mathrm{mg} / \mathrm{mL}, 11) .0 .04 \mathrm{mg} / \mathrm{mL}, 12) .0 .02 \mathrm{mg} / \mathrm{mL}$

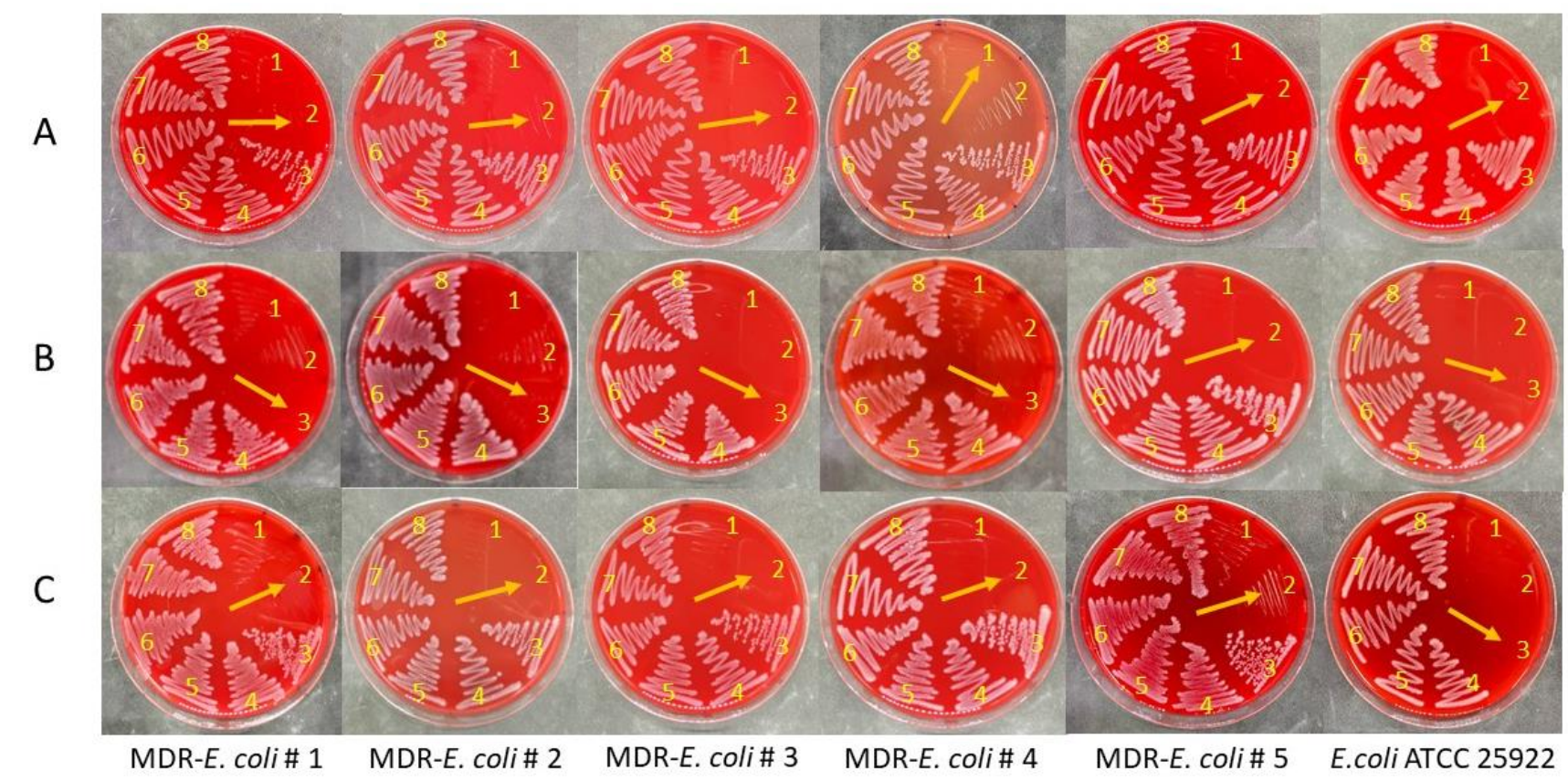

Figure 3. MBC values of A. lanceipolius, A. elasticus and A. odoratissimus seed extract against MDR-E. coli: A) A. lanceipolius, B) A. elasticus, C). A. Odoratissimus. Concentrations: 1). $50 \mathrm{mg} / \mathrm{mL}, 2) .25 \mathrm{mg} / \mathrm{mL}, 3) .12 .5 \mathrm{mg} / \mathrm{mL}, 4) .6 .25 \mathrm{mg} / \mathrm{mL}, 5) .3 .13 \mathrm{mg} / \mathrm{mL}, 6$ ). $1.56 \mathrm{mg} / \mathrm{mL}, 7) .0 .78 \mathrm{mg} / \mathrm{mL}, 8) .039 \mathrm{mg} / \mathrm{mL}, \longrightarrow:$ MBC values

The results of this study can be concluded that the seed ethanol extract of three species of Artocarpus, namely A. lanceipolius, A. elasticus, and A. odoratissimus has the potential as antibacterial agents against MDR-E. coli. However, previous research by Eve et al. (2020) showed that the ethanol extract of A. heterophyllus seeds which is a member of the genus Artocarpus did not have antibacterial activities against MDR-E. coli.

\section{Determination of MIC and MBC value}

The MIC value of the seed ethanol extracts of $A$. lanceipolius, A. elasticus, and A. odoratissimus against MDR-E. coli from UTI patients were performed by the microdilution method using a microwell plate, as shown in Figure 2. The results revealed that the MIC values of the three extracts ranged from $12.5 \mathrm{mg} / \mathrm{mL}$ to $6.25 \mathrm{mg} / \mathrm{mL}$. The A. elasticus seed extract showed better antibacterial activity than the other two extracts because it had a lower MIC value of $6.25 \mathrm{mg} / \mathrm{mL}$ for almost all MDR-E. coli. MDR-E coli \#5 was the only isolate with a MIC value of $25 \mathrm{mg} / \mathrm{mL}$. MDR-E. coli $\# 5$ is (ESBL)-which is an E. coli + carbapenem-resistant producer, so this isolate might be more resistant to antibacterial agents.

The results of this study also showed better MIC value than some previous studies. Seed extracts of $A$. heterophyllus, A. champeden, and A. camansi against methicillin-resistant Staphylococcus aureus (MRSA) had MIC values of $15.62 \mathrm{mg} / \mathrm{mL}$ (Prastiyanto et al. 2020a). A. heterophyllus seed extract had a MIC value of $125 \mathrm{mg} / \mathrm{mL}$ against MDR-Pseudomonas aeruginosa (Eve et al. 2020). 
The MBC value of the seed ethanol extracts of $A$. lanceipolius, A. elasticus, and A. odoratissimus against MDR-E. coli was determined by the microdilution method using a mixture of MIC cultures in a microwell plate and cultured on BAP media, as presented in Figure 3. The results exhibited that three extracts had MBC values ranging from 25 to $12.5 \mathrm{mg} / \mathrm{mL}$. A. elasticus seed extract showed better results than the other two extracts because it had a lower MBC value of $12.5 \mathrm{mg} / \mathrm{mL}$ for almost all MDR and only MDR-E. coli \#5, which was (ESBL)- E. coli + carbapenem-resistant producer, showed an MBC value of $25 \mathrm{mg} / \mathrm{mL}$. The results of this study presented better values of MBC than previous studies. The MBC values of seed extracts of A. heterophyllus, A. champeden, and A. camansi against MRSA were $62.25 \mathrm{mg} / \mathrm{ml}, 31.25 \mathrm{mg} / \mathrm{ml}$, and 250 $\mathrm{mg} / \mathrm{ml}$, respectively.) (Prastiyanto et al. 2020a). Another study reported that $A$. heterophyllus leaf extracts did not have antibacterial activities against $E$. coli, as indicated by MIC and MBC values of 0 (Mishra and Padhy 2013).

\section{Phytochemical screening of extracts}

Qualitative screening of phytochemical contents, i.e., flavonoids and tannins, were carried out on all extracts (Table 4).

The results revealed that all seed extracts contain flavonoids and tannins. Flavonoids are secondary metabolites of 2-phenyl-benzyl- $\gamma$-pyrone derivatives and these compounds are most commonly found in plants (Buer et al. 2010) because flavonoids are compounds that are known to be synthesized by plants in response to infection (Panche et al. 2016). According to Cushnie and Lamb (2005), many compounds of flavonoids have the potential as antibacterial agents (Cushnie and Lamb 2005). In this study, the mechanism of inhibition of MDR-E. coli by flavonoids from Artocarpus seed extracts was not known yet. However, quercetin, apigenin, and 3,6,7,3 ', 4'pentahydroxyflavone were reported as gyrase DNAinhibiting flavonoids of E. coli (Ohemeng et al. 1993).

Tannins were also contained in all Artocarpus seed extracts. Tannins are the most abundant polyphenols in edible plants (Chung et al. 1998). Many studies reported the potential of tannins as antibacterial agents. A previous study (Dabbaghi et al. 2019) reported the antibacterial activities of tannins against $E$. coli was depend on the content of phenolic hydroxyl groups. However, the inhibition mechanism of tannins in Artocarpus seed extracts was not performed in this study. Several previous research suggested that tannins interfere with cell metabolism (Belhaoues et al. 2020).

Table 4. The results of the phytochemical analysis of seed extracts

\begin{tabular}{lcc}
\hline \multirow{2}{*}{ Seed extract } & \multicolumn{2}{c}{ Phytochemicals content } \\
\cline { 2 - 3 } & Flavonoids & Tannins \\
\hline A. lanceipolius & + & + \\
A. elasticus & + & + \\
A. odoratissimus & + & + \\
\hline
\end{tabular}

In conclusion, the seed extracts of three Artocarpus species are potential to be developed as an antibacterial against UTI-causing MDR-E. coli. A. elasticus seed extract has better potency than the other two seed extracts. Further in vivo research and study regarding the mode of action are necessary to be carried out.

\section{ACKNOWLEDGEMENTS}

The authors would like to thank Isti Rahayati, Andi Tenriyola Syakir, Widya Perwati, and Dea Ayu Maharani from the Department of Medical Laboratory Technology, Universitas Muhammadiyah Semarang, Indonesia for the assistance in collecting Artocarpus samples in Eat Kutai District (East Kalimantan), Luwu District (South Sulawesi), and Tabalong District (South Kalimantan), Indonesia.

\section{REFERENCES}

Adwan K, Jarrar N, Abu-Hijleh A, Adwan G, Awwad E. 2014. Molecular characterization of Escherichia coli isolates from patients with urinary tract infections in Palestine. J Med Microbiol 63: 229-234. DOI: 10.1099/jmm.0.067140-0

Behzadi P, Behzadi E, Yazdanbod H, Aghapour R, Akbari M, Omran D. 2010. Urinary Tract Infections Associated With Pregnancy. J Am Med Assoc 101: 1928. DOI: 10.1001/jama.1933.02740500008003

Belhaoues S, Amri S, Bensouilah M. 2020. Major phenolic compounds, antioxidant and antibacterial activities of Anthemis praecox Link aerial parts. South Afr J Bot 131: 200-205. DOI: 10.1016/j.sajb.2020.02.018

Buer CS, Imin N, Djordjevic MA. 2010. Flavonoids: New roles for old molecules. J Integr Plant Biol 52: 98-111. DOI: 10.1111/j.17447909.2010.00905.x

Chung KT, Wong TY, Wei CI, Huang YW, Lin Y. 1998. Tannins and human health: A review. Crit Rev Food Sci Nutr 38: 421-464. DOI: 10.1080/10408699891274273

CLSI. 2019. M100 Performance Standards for Antimicrobial Susceptibility Testing, 29th ed. J Serv Marketing. DOI: 10.1108/08876049410065598

CLSI. 2018. M07: Methods for Dilution Antimicrobial Susceptibility Tests for Bacteria That Grow Aerobically, 11th Edition. CLSI.

Cushnie TPT, Lamb AJ. 2005. Antimicrobial activity of flavonoids. Int J Antimicrob Agents 26: 343-356. DOI: 10.1016/j.ijantimicag.2005.09.002

Dabbaghi A, Kabiri K, Ramazani A, Zohuriaan-Mehr MJ, Jahandideh A. 2019. Synthesis of bio-based internal and external cross-linkers based on tannic acid for preparation of antibacterial superabsorbents. Polym Adv Technol 30: 2894-2905. DOI: 10.1002/pat.4722

Edlin RS, Shapiro DJ, Hersh AL, Copp HL. 2013. Antibiotic resistance patterns of outpatient pediatric urinary tract infections. J Urol 190: 222-227. DOI: 10.1016/j.juro.2013.01.069

Eve A, Aliero AA, Nalubiri D, Adeyemo RO, Akinola SA, Pius T, Nabaasa S, Nabukeera S, Alkali B, Ntulume I. 2020. In vitro antibacterial activity of crude extracts of Artocarpus heterophyllus seeds against selected diarrhoea-causing superbug bacteria. Sci World J 2020. DOI: 10.1155/2020/9813970

Lestari SD, Sadiq ALO, Safitri WA, Dewi SS, Prastiyanto ME. 2019. The antibacterial activities of bacteriocin Pediococcus acidilactici of breast milk isolate to against methicillin-resistant Staphylococcus aureus. J Phys Conf Ser 1374: 012021. DOI: 10.1088/17426596/1374/1/012021

Mazzariol A, Bazaj A, Cornaglia G. 2017. Multi-drug-resistant Gramnegative bacteria causing urinary tract infections: A review. J Chemother 29: 2-9. DOI: 10.1080/1120009X.2017.1380395

Millner R, Becknell B. 2019. Urinary tract infections. Pediatr Clin North Am 66: 1-13. DOI: 10.1016/j.pcl.2018.08.002 
Mishra MP, Debata NK, Padhy RN. 2013. Surveillance of multidrug resistant uropathogenic bacteria in hospitalized patients in Indian. Asian Pac J Trop Biomed 3: 315-324. DOI: 10.1016/S22211691(13)60071-4

Mishra MP, Padhy RN. 2013. In vitro antibacterial efficacy of 21 Indian timber-yielding plants against multidrug-resistant bacteria causing urinary tract infection. Osong Publ Health Res Perspect 4: 347-357. DOI: $10.1016 /$ j.phrp.2013.10.007

Mukherjee M, Basu S, Mukherjee SKM, Majumder M. 2013. Multidrugresistance and extended spectrum beta-lactamase production in uropathogenic E. coli which were isolated from hospitalized patients in Kolkata, India. J Clin Diagn Res 7: 449-453. DOI: 10.7860/JCDR/2013/4990.2796

Ohemeng KA, Schwender CF, Fu KP, Barrett JF. 1993. DNA gyrase inhibitory and antibacterial activity of some flavones(1). Bioorganic Med Chem Lett 3: 225-230. DOI: 10.1016/S0960-894X(01)80881-7

Panche AN, Diwan AD, Chandra SR. 2016. Flavonoids: an overview A. J Nutr Sci 5: 1-15. DOI: 10.1017/jns.2016.41

Prastiyanto ME, Rohmah N, Efendi L, Arifin R, Wardoyo FA, Wilson W, Mukaromah A, Dewi S, Darmawati S. 2021a. Antifungal activities of the rhizome extract of five member Zingiberaceae against Candida albicans and Trichophyton rubrum. Biodiversitas 22: 1509-1513. DOI: 10.13057/biodiv/d220355

Prastiyanto ME, Dewi N, Pratiningtias T, Pratiwi N, Windayani A, Wahyunengsih E, Astuti, Amir E, Wardoyo F. 2021b. In vitro antibacterial activities of crude extracts of nine plants on multidrug resistance bacterial isolates of wound infections. Biodiversitas 22: 2641-2647. DOI: 10.13057/biodiv/d220712

Prastiyanto ME, Azizah IH, Haqi HD, Yulianto BD, Agmal AB, Radipasari ZD, Astuti NAD. 2020a. In-vitro antibacterial activity of the seed extract of three member Artocarpus towards methicillin resistant Staphylococcus aureus (MRSA). J Teknol Lab 9: 1-6. DOI: 10.29238/tek [Indonesian]

Prastiyanto ME, Rukmana RM, Saraswati DK, Darmawati S, Maharani ETW, Tursinawati Y. 2020b. Anticancer potential of methanolic extracts from Pleurotus species on raji cells and antibacterial activity against Methicillin-Resistant Staphylococcus aureus. Biodiversitas 21: 5644-5649. DOI: 10.13057/biodiv/d211221

Prastiyanto ME, Setyaningtyas A, Trisnawati L, Syafira A. 2016. Antimicrobial activity and identification the compounds of methanol extract from the Pleurotus ostreatus fruiting body. el-Hayah 6: 29-34. DOI: 10.18860/elha.v6i1.4082

Prastiyanto ME, Tama PD, Ananda N, Wilson W, Mukaromah AH. 2020c. Antibacterial potential of Jatropha sp. latex against multidrugresistant bacteria. Int J Microbiol 2020. DOI: 10.1155/2020/8509650

Prastiyanto ME, Wardoyo FA, Wilson W, Darmawati S. $2020 \mathrm{~d}$. Antibacterial activity of various extracts of Averrhoa bilimbi against multidrug resistant bacteria. Biosaintifika 12: 163-168. DOI: 10.15294/biosaintifika.v12i2.23600 [Indonesian]

Sbihi HM, Nehdi IA, Mokbli S, Romdhani-Younes M, Al-Resayes SI. 2018. Hexane and ethanol extracted seed oils and leaf essential compositions from two castor plant (Ricinus communis L.) varieties. Ind Crops Prod 122: 174-181. DOI: 10.1016/j.indcrop.2018.05.072

Simões e Silva AC, Oliveira EA, Mak RH. 2020. Urinary tract infection in pediatrics: an overview. J Pediatr (Rio J) 96: 65-79. DOI: 10.1016/j.jped.2019.10.006

Tsukatani T, Higuchi T, Suenaga H, Akao T, Ishiyama M, Ezoe T, Matsumoto K. 2009. Colorimetric microbial viability assay based on reduction of water-soluble tetrazolium salts for antimicrobial susceptibility testing and screening of antimicrobial substances. Anal Biochem 393 (1): 117-125. DOI: 10.1016/j.ab.2009.06.026

Yin C, Xie L, Guo Y. 2018. Phytochemical analysis and antibacterial activity of Gentiana macrophylla extract against bacteria isolated from burn wound infections. Microb Pathog 114: 25-28. DOI: 10.1016/j.micpath.2017.10.049

Zubair KU, Shah AH, Fawwad A, Sabir R, Butt A. 2019. Frequency of urinary tract infection and antibiotic sensitivity of uropathogens in patients with diabetes. Pak J Med Sci 35: 1664-1668. DOI: 10.12669/pjms.35.6.115 